\title{
Ia zero energia kontsumitzen duten eraikinen ezagutza zientifikoaren analisia
}

\author{
(Analysis of scientific knowledge of nearly zero energy buildings) \\ Izaskun Alvarez Meaza*, Enara Zarrabeitia Bilbao, \\ Itziar Martinez de Alegria Mancisidor, Jasone Aranburu
}

Enpresen Antolakuntza Saila, Bilboko Ingeniaritza Eskola (UPV/EHU)

LABURPENA: Eraikuntza-sektorearen energia-kontsumoa jaistera bideratutako ahaleginek energia balantzea ia zero energia kontsumitzen duten eraikinen (Nearly Zero Energy Buildings, $N Z E B$ ) kontzeptuaren garapena ekarri dute Europar Batasunean. Lan honen helburuak dira, batetik, ia zero energia kontsumitzen duten eraikinen inguruko ezagutza zientifikoaren joeraren ikuspegi orokorra eskuratzea, eta, bestetik, Passivhaus etxebizitzen ezaugarri energetikoak definitzen dituzten parametroen arteko erlazioek jarraitzen dituzten ereduak edo patroiak aztertzea. Web of Science (WoS) datu-basea erabiliz, zientziaren ikerketa-esparrua garatu eta bistaratu da, eta analizatu dira argitalpen urteak, herrialde, aldizkari eta erakunde garrantzitsuenak, gehien aipatu diren artikuluak eta teknologia-jardueren bideak. Emaitza orokorrek adierazten dute ia zero energia kontsumitzen duten eraikinen filosofia aditasun handia ari dela eskuratzen zientziaren arloan. Ikerketa-lanak nagusiki Europan bildu dira, bai eta artikulu gehien argitaratzen dituzten erakundeak ere.

HITZ GAKOAK: NZEB, Passivhaus, bibliometria, data-mining, ezagutza-mapak.

ABSTRACT: Channelled efforts to lower energy consumption in the construction sector have led to the development of the NZEB (nearly zero energy buildings) concept in the European Union. The objectives of this work are to get an overview of the trend of scientific knowledge about NZEB buildings, and to examine the patterns or models that follow the relationships between the parameters that define the energy characteristics of Passivhaus dwellings. Through the Web of Science (WoS) database different aspects have been developed and visualized, the research field of science, the years of publication, country, journal, and the most important institutions, the articles that have been mentioned most often, analyzing the paths of technology activities. The general results express the great attention that the NZEB philosophy is getting in the field of science. Research work has been concentrated mainly in Europe, as have the institutions that publish most of the articles.

KEYWORDS: NZEB, Passivhaus, Bibliometrics, data-minig, knowledge-networks.

\footnotetext{
* Harremanetan jartzeko / Corresponding author: Izaskun Alvarez Meaza, Enpresen Antolakuntza Saila, Bilboko Ingeniaritza Eskola (UPV/EHU), Ingeniero Torres Quevedo Enparantza 1 (48013 Bilbo-Bizkaia), Euskal Herria. - izaskun.alvarez@ehu.eus https://orcid.org/0000-0002-2110-0719.

Nola aipatu / How to cite: Alvarez Meaza, Izaskun; Zarrabeitia Bilbao, Enara; Martinez de Alegria Mancisidor, Itziar; Aranburu, Jasone (2019). «la zero energia kontsumitzen duten eraikinen ezagutza zientifikoaren analisia»; Ekaia, 36, 2019, 225-237. (https://doi.org/10.1387/ekaia.20421).

Jasoa: 27 azaroa, 2018; Onartua: 27 martxoa, 2019

ISSN 0214-9001 - elSSN 2444-3255 / (C) 2019 UPV/EHU

(c) (i) (-) Obra hau Creative Commons Atribución 4.0 Internacional-en

BY NC SA lizentziapean dago
} 
Izaskun Alvarez, Enara Zarrabeitia Bilbao,

Itziar Martinez de Alegria Mancisidor, Jasone Aranburu

\section{SARRERA}

Gaur egungo gizartearen arazo larrienetako bat berotze globalaren fenomenoa da, zeina berotegi-efektuaren ondorioz areagotu baita azken hamarkadetan. Azpimarratzekoa da energia primarioaren kontsumo globalaren $\%$ 30-40 eta berotegi efektuko gasen emisio globalaren \% 24 eraikuntzasektoretik datorrela $[1,2]$. Europaren kasuan, zehazki, eraikuntza-sektoretik datoz energia primarioaren eskariaren $\% 40$ eta $\mathrm{CO}_{2}$ emisioen \% 36. Izan ere, efizientzia energetikoa da lehen urratsa Europako karbono emisioak $\% 80$ murrizteko anbizio handiko helburua lortzeko [3].

Europar Batasuneko (EB) eraikinen \% 3550 urtetik gorakoak dira, eta eraikinak osotara hartuta, soilik \% 75 da energetikoki ez-efizientea. Hori dela eta, existitzen diren eraikinetan berrikuntzak egiteak energia asko aurreztea lortuko luke, zeinari esker posible izango bailitzateke EBko energia-kontsumo totala \% 5-6 gutxitzea eta $\mathrm{CO}_{2}$ emisioak \% 5 jaistea [4].

Eraikinen efizientzia energetikoa hobetzeak onura ekonomikoa, soziala eta ingurumenarekiko jasangarritasuna ekarriko lituzke. Errendimendu handiagoko eraikinek erosotasun-maila handiagoa eta bizilagunen ongizatea eragiten dute, bai eta osasuna hobetu ere, eta etxe barruko klima eskasaren ondoriozko gaixotasunak murriztu. Horrez gain, errendimendu energetikoak eragin zuzena du etxebizitzen gastuei aurre egiteko ahalmenean eta pobrezia energetikoan, eraikinen efizientziaren hobekuntzak pobrezia energetikoa leuntzea ahalbidetzen baitu. Etxebizitza batek pobrezia energetikoa pairatzen duela esaten da, baldin eta berogailu, hozte-sistema, argiztapen eta etxetresna elektrikoekin bat doazen energia-zerbitzu egokien gabezia badu [5,6]. Energia-zerbitzu horiek beharrezkoak dira bizi-maila duina izateko eta biztanleen osasunerako.

Eraikuntza-sektorea erronka handiak izaten ari da era honetako arazoen aurrean: energia-kontsumoa, aldaketa klimatikoa eta pobrezia energetikoa. Gainera, energiaren prezioak denbora luzez izan duen joera gorakorrak garapen-bidean dagoen energia berriztagarrien merkatuarekiko interesa piztu du, eta horrekin batera, energia berriztagarrien teknologien kostuak jaitsi egin dira: esaterako, eguzkitiko energia fotovoltaikoarena. Horrek, eraikuntza-sektorean garapen berrietarako bide berriak sustatu ditu. Garapen horietako bat izan liteke etxebizitza eta eraikin komertzial jasangarriagoak diseinatzea, eta jada eginak diren eraikinak egokitzea energia neutraltasuna lortzeko, hau da, eraikinak kontsumitzen duen energia kopuru bera sortzeko ahalmena izateko [7].

Errealitate horren aurrean, Europako Parlamentuak Nearly Zero Energy Buildings (NZEB) edo energia kontsumoa ia nulua duten eraikuntzak izeneko kontzeptua garatu zuen, zeinaren ezaugarriak baitira energia eskari 
oso baxua izatea eta tokian bertan ekoiztutako energia berriztagarria erabiltzea. Izan ere, 2050. urterako ezarritako helburua karbono-emisioak \% 80 gutxitzea da, eta, bide horretan, energia efizientzia lortzea da eman beharreko lehen pausoa[3].

Eraikinen efizientzia energetikoa hobetzea Europar Batasunaren lehentasunezko arazo bihurtu den honetan, EBko Energy Performance of Building Directive (EPBD) (2010/31/EC) izeneko zuzentarauak batasuneko kide diren Estatuei eraikinak energetikoki efizienteak izateko neurriak ezartzea eskatzen die, energia primarioaren erabilera murrizteko, besteak beste. Zuzentarau horrek ezarririko helburuak betetzea da datozen urteetarako erronka handienetakoa Europako herrialdetako eraikuntza-sektorearentzat. Izan ere, 2020. urte amaierarako eraikin berri guztiak NZEB motakoak izatea eskatzen da. Eraikin publiko berri guztietarako, berriz, NZEB izatea eskatzen da 2018. urterako. Horretarako, eraikinen diseinu, eraikuntza eta antolakuntzen prozedurak aldatzea eskatzen da, hiri zein eraikuntzen efizientzia energetiko handiagoa lortzeko.

Horri erantzunez, herrialde bakoitzak independenteki jardun du etxebizitzek bete beharreko parametroak ezartzeko garaian. Suedian, esaterako, eraikinen energia efizientziaren estandar zorrotz bat jarri zen abian, onartze-irizpideak batezbesteko U-balioaren metodo orokorretik errendimendu energetikoaren metodora aldatuz. Errendimendu energetikoaren metodoak eraikitako azalera $\mathrm{m}^{2}$ bakoitzeko erabiliko den energia kantitatearen balio maximo bat ezartzen du. Batezbesteko U-balioaren metodo orokorrak, berriz, eraikinaren inguratzaile osoarentzako transmisio-faktore termikoaren balio maximoa ezartzen du. Danimarkak ere eredu berri bat aplikatu zuen marko energetikoaren metodoan oinarrituta, zeinak energia galera balio maximo bat ezartzen baitu eraikitako $\mathrm{m}^{2}$ bakoitzeko. Erresuma Batuan eraikuntzaren araudiko energia-kontserbazioaren atalaren berrikusketa egin zen, onartze-irizpideak aldatuz funtsezko U-balioaren metodotik errendimendu energetikoaren metodora. Espainiaren kasuan, eraikinen elementuentzat ezarririko U-balio maximoa zorroztu zen, eraikinen inguratzaileen errendimendu energetikoaren hobekuntza handiagoa lortzeko. Energia-kontsumo baxuko eraikina lortzeko hainbat eredu diren arren, «Passivhaus» izeneko estandarra asko hedatu da Europan, eta gero eta arreta handiagoa ari da irabazten[2].

Horregatik guztiagatik, ikerketa honen helburu nagusia honako hau da: ia zero energia kontsumitzen duten eraikinen inguruko ezagutza zientifikoaren joeraren ikuspegi orokorra eskuratzea, zientzia-neurketa aztertzen duen analisi baten bidez. 
Izaskun Alvarez, Enara Zarrabeitia Bilbao,

Itziar Martinez de Alegria Mancisidor, Jasone Aranburu

\section{METODOLOGIA}

Analisi honetan, 1. irudian deskribatzen den prozesu analitikoa inplementatu da, aurrerago azalduko dena.

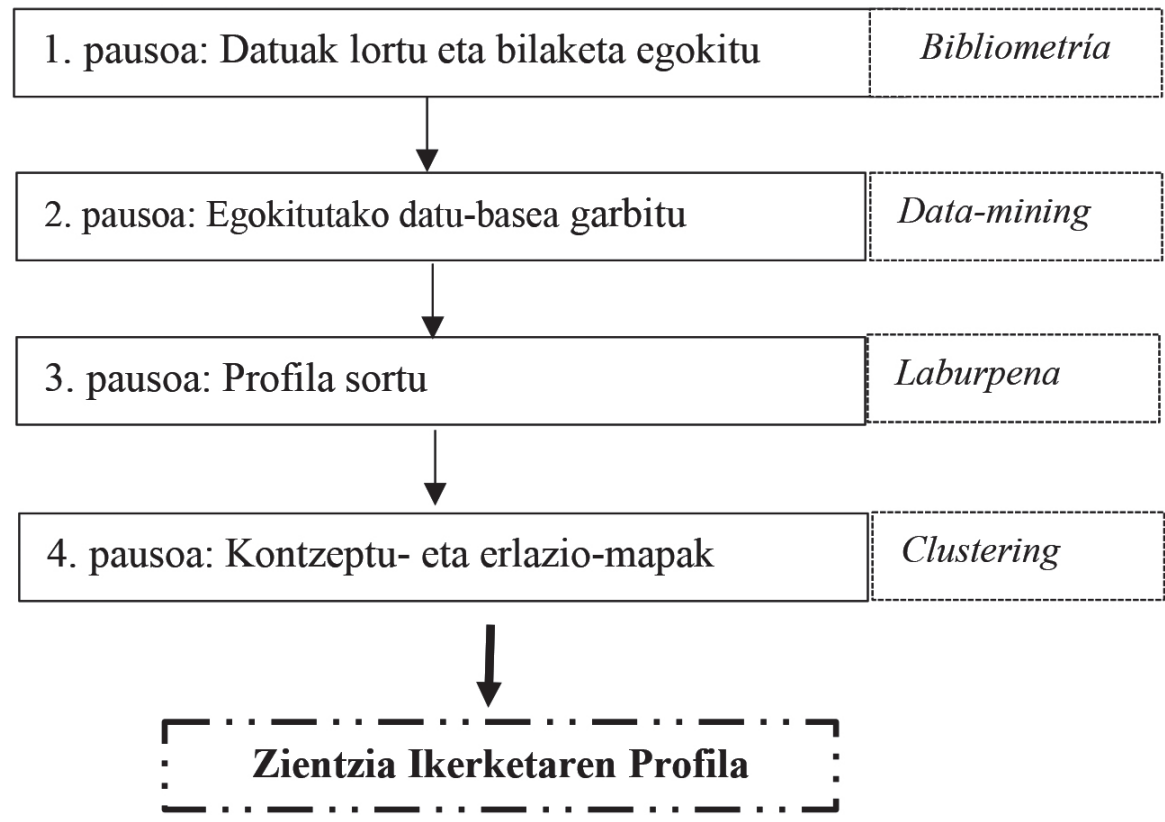

1. irudia. Ikerketaren prozedura analitikoa urratsez urrats.

Lanaren helburua lortzeko lau pauso eman dira:

1. Pausoa: Datuak lortu eta bilaketa egokitu: Lehenengo jarduera argitalpen zientifikoen datu-basea sortzea da. Horretarako, Web Of Science $^{\mathrm{TM}}$ (WoS) Core Collection datu-basetik ia zero energia kontsumitzen duten eraikinen erregistro bibliografikoen datuak lortu dira bilaketa-galdera bat erabiliz. Bestalde, WoS datu-basea edozein jakintzagaitako argitalpen zientifiko nagusien erreferentziak jasotzen dituen Web teknologian oinarritutako plataforma da. Mundumailan, WoS Core Collection argitalpen zientifikoen datu-baseen buru bihurtu da, eragin handiko 20.000 aldizkari baino gehiago dituena [8]. WoS datu-basean bilaketa arrakastatsua izan dadin, oso garrantzitsua da bilaketa-galdera ondo definitzea; izan ere, horri esker bilaketa gure interesen arabera mugatzea lortuko da. Literatura azterketa hori egiteko terminologia aukeratzeko garaian, kontuan izan behar da kontzeptu bera adierazteko termino ezberdinak era- 
bil daitezkeela. Halaber, galderan erabiltzen den izartxoa (*) hitzek izan ditzaketen aldaerak bilaketan barne hartzeko ipintzen da: adibidez, «low energy building» eta «low energy buldings» bezalako aldaera posibleak kontuan izateko. 1. taulan ikus daitekeen moduan, galderarekin bat datorren erregistroa 1981. urtean argitaratu zen, eta orduz geroztik 823 argitalpen izan dira.

1. taula. Ia zero energia kontsumitzen duten eraikinei buruzko artikuluak bilatzeko galdera, Web Of Science (WoS) datu-basera egokituta.

\begin{tabular}{c|l}
\hline Gaia & \multicolumn{1}{c}{ Datuak } \\
\hline Ekuazioa edo galdera & $\begin{array}{l}\text { TS = (passivhaus OR «passivehouse» OR NZEB or «nearly zero } \\
\text { energy building*» OR «low energy building*») }\end{array}$ \\
\hline Iturria & WoS \\
\hline Datu-basea & Bilduma nagusia (Core Collection) \\
\hline Denbora tartea & 1981etik 2018ko maiatzera \\
\hline Hizkuntza & Ingelesa \\
\hline Dokumentu mota & Artikuluak \\
\hline Bilaketa data & 2018 ko apirilaren 30a \\
\hline Emaitzak & 823
\end{tabular}

2. Pausoa: Egokitutako datu-basearen garbiketa. Urrats hau gauzatzeko, data-mining tresnak behar ditugu. Egokitutako argitalpen zientifikoen datu-basea VantagePoint (VP) softwarera inportatu da. Horren bitartez, landu gabeko datuetatik alorrak identifikatu ahal izango ditugu eta emaitzak aurkeztuko dira estatistika-konbinazio bat bezala. Egile, herrialde, erakunde, aldizkari eta gako-hitz alorretan fuzzy matching (bat datorren lausoa) teknika erabiltzen da garbiketa egiteko, hitzen aldaerak (sinonimoak, pluralak eta antzeko esanahiak, besteak beste) taldekatzeko helburuarekin.

3. Pausoa: Profilaren sorkuntza. Zientzia-ikerketaren profila bibliografia eta ikerketa komunitatearen profilean oinarritzen da. Ikerketa-jarduera deskribatu egiten da, argitalpen kopuruaren joera, herrialde, erakunde, aldizkari nagusiak eta gehien aipatzen diren artikuluak identifikatuz.

4. Pausoa: Kontzeptu- eta Erlazio-mapak. Urrats honen sarrera egokitutako datu-basea izango da. VP software tresna erabiliz, bat-etortze matrizeak definituko dira, eta $R$ software eta VOSviewer bistaratze eta clustering software erabiliz Kontzeptu-mapak eta Erlazio-mapak sortzen dira [9-11]. 
Izaskun Alvarez, Enara Zarrabeitia Bilbao,

Itziar Martinez de Alegria Mancisidor, Jasone Aranburu

\section{EMAITZAK}

Atal honetan, aurretik azaldutako metodologiari jarraituz lortu diren emaitzak aurkeztuko dira.

\subsection{Zientzia-ikerketaren profila ia zero energia kontsumitzen duten eraikinetan}

1981etik 2017ra ia zero energia kontsumitzen duten eraikinen ezagutza zientifikoaren produkzioa aztertzeko, WOSen egin den analisian lortutako emaitzak 2-5 irudietan erakusten dira. Emaitza orokorretan ikus daiteke, azken urteetan, energia-kontsumo baxuko eraikinak azkar ari direla arreta berenganatzen zientziaren ekoizpenari dagokionez, eta horrek zuzenean eragiten du arlo horren I+Gn. 2. irudian ikusten den bezala, 2000. urtean 4 argitalpen zientifiko soilik zeuden, eta 2017. urterako, aldiz, zifra hori 141 era igo zen, \% 3.525eko igoera esan nahi duena. Gainera, argitaratutako 823 dokumentu zientifikoen \% 67,31 azken 5 urteetan argitaratu dira (2013-2017 bitartean): zifra horiek energia-kontsumo baxuko eraikinen berritasunaren eta interesaren isla dira. Bestalde, datuen joera-lerroak erregresio esponentzial bat jarraitzen du, non zehaztapen koefizientea $0,9011 \mathrm{koa}$ denetz.

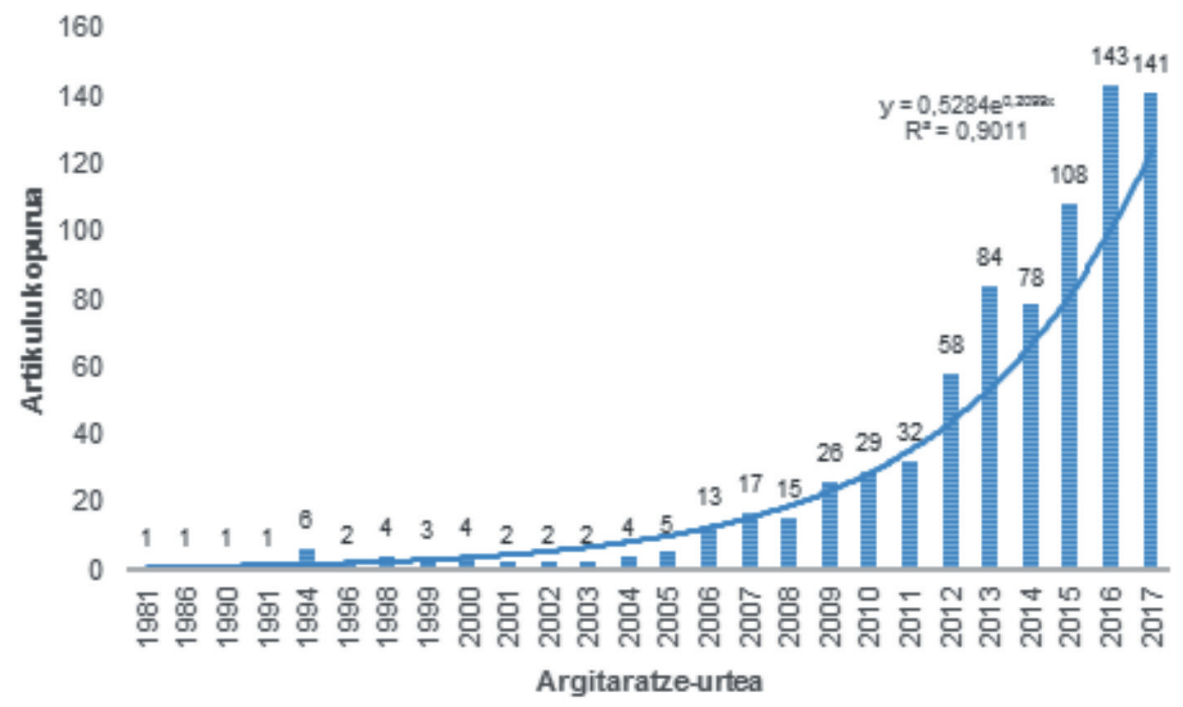

2. irudia. Urtero argitaratutako artikulu kopurua WoS-en, 1981etik 2017ra.

Gai honen inguruko argitalpenei dagokienez, argitaratzen emankorrenak diren 10 herrialdeak ez daude geografikoki kontzentratuta (3. irudia). 
Nabarmen gailentzen den herrialdea, argitalpen zifra handienarekin, Italia da, hangoak baitira argitalpen guztien \% 11 (95 dokumentu). Erresuma Batua, 78 artikulurekin, bigarren kokatzen da. Halaber, Erresuma Batuaren ondoren datozen AEB, Suedia eta Txina ez dira Erresuma Batuaren argitalpen kopurutik asko aldentzen, hau da, nahikoa hurbiletik jarraitzen diote: 54 argitalpenekin AEBen kasuan, eta 52rekin Suediaren kasuan. Lehenengo 10 herrialdeen arteko gainerako herrialdeek 46 eta 33 dokumentu bitartean dituzte argitaratuta, eta denak Mendebaldeko Europan, Amerikan edo Asiako ekialdean kokatzen dira.

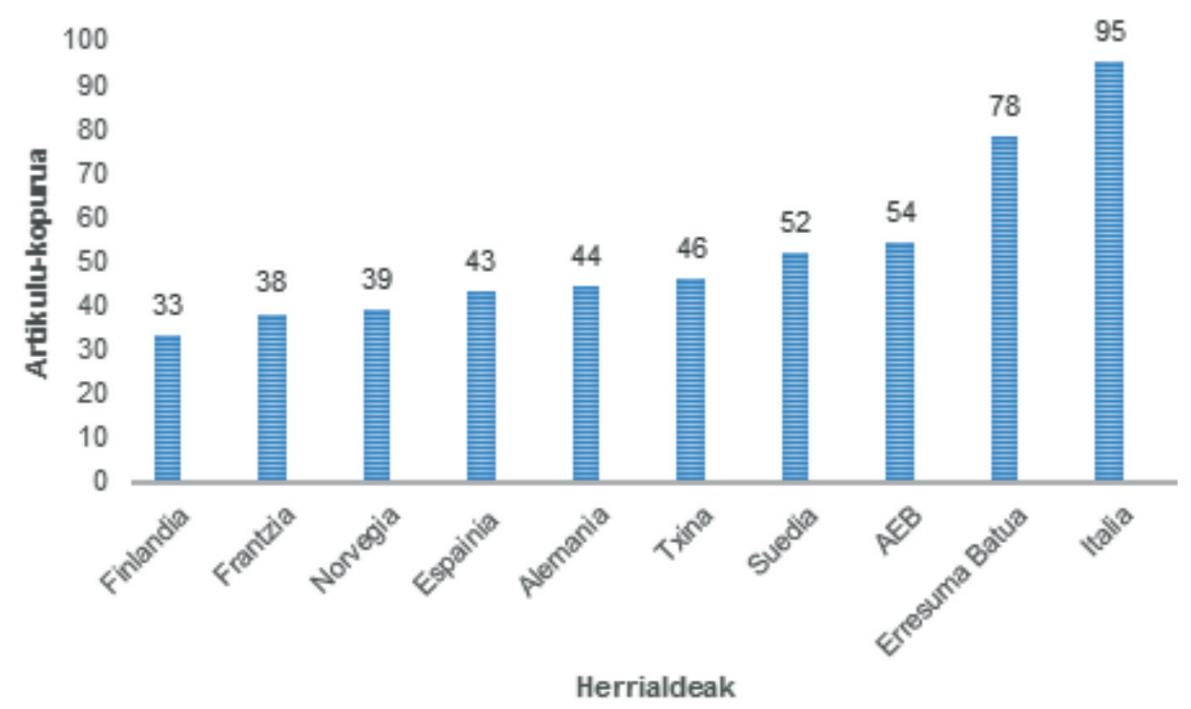

3. irudia. WoSen artikulu gehien publikatutako 10 herrialdeak.

4. irudian agertzen diren 10 erakundeak, energia-kontsumo baxuko eraikinen inguruko argitalpen kopuruei dagokienez gailentzen diren erakundeak dira, eta horien jatorriak zerikusia du aurretik azaldutako 10 herrialde nagusiekin. Esate baterako, erakunde hauek gehien publikatzen duten herrialdeetan daude, hau da, Italia (2), Norvegia, Finlandia eta Erresuma Batua. Baina salbuespenak ere badira: adibidez, Danimarkan, Errumanian, Estonian, Eslovenian eta Lituanian dauden erakundeak. Hala ere, kasu honetan, artikulu-banaketa askoz ere orekatuagoa da; beraz, ezagutzaren erakunde-jatorria nahikoa sakabanatuta dago, eta ez erakunde gutxitan bakarrik kontzentratua. Lau erakunde nagusiak hauek dira: Norwegian Univ Sci \&Technol (Norvegia, 32 artikulu), Aalto Univ (Finlandia, 26 artikulu), Tech Univ Denmark (Danimarka, 19 artikulu) eta Univ Politehn Bucuresti (Errumania, 18 artikulu). Gainerako erakundeen argitalpen kopuruek oso gertutik jarraitzen diete 4 erakunde nagusi horiei. 


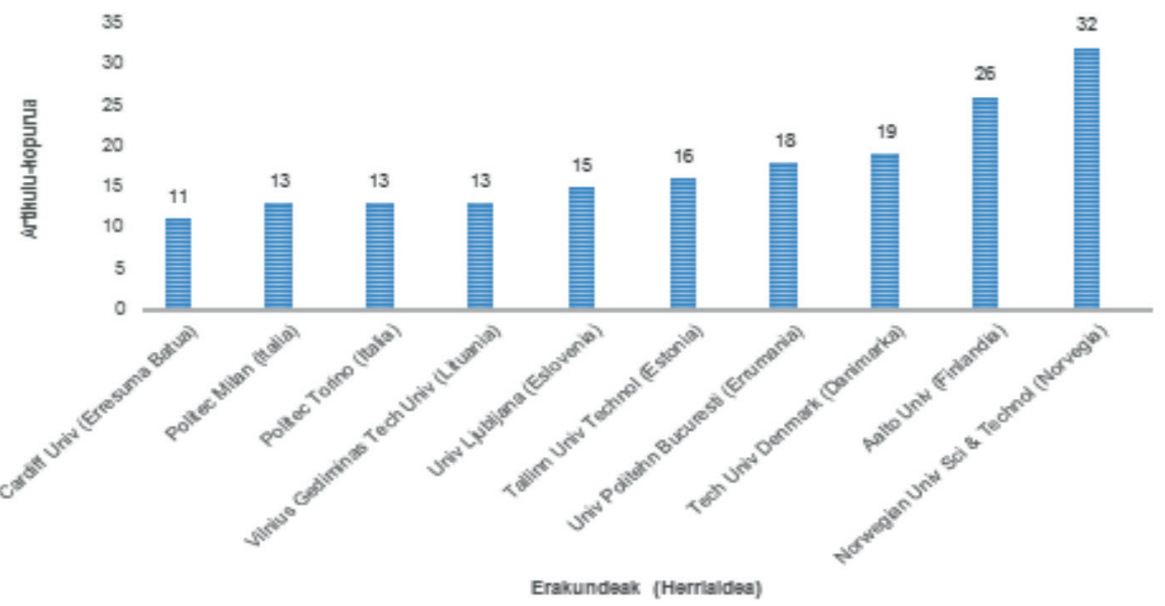

4. irudia. WoSen artikulu gehien publikatutako 10 erakundeak.

Energia-kontsumo baxuko eraikinen inguruan emankorrenak diren aldizkariak aztertu dira. 10 aldizkari garrantzitsuenak 5. irudian ikus daitezke. Energy and Buildings, 225 artikulurekin, aldizkari garrantzitsuena da, zehazki artikulu zientifikoen \% 27,33 argitaratzen ditu. Gainera, aldizkari horiek Clarivate Analytics-en Journal Citation Report-en indexatuta daude inpaktu-faktore handiekin.

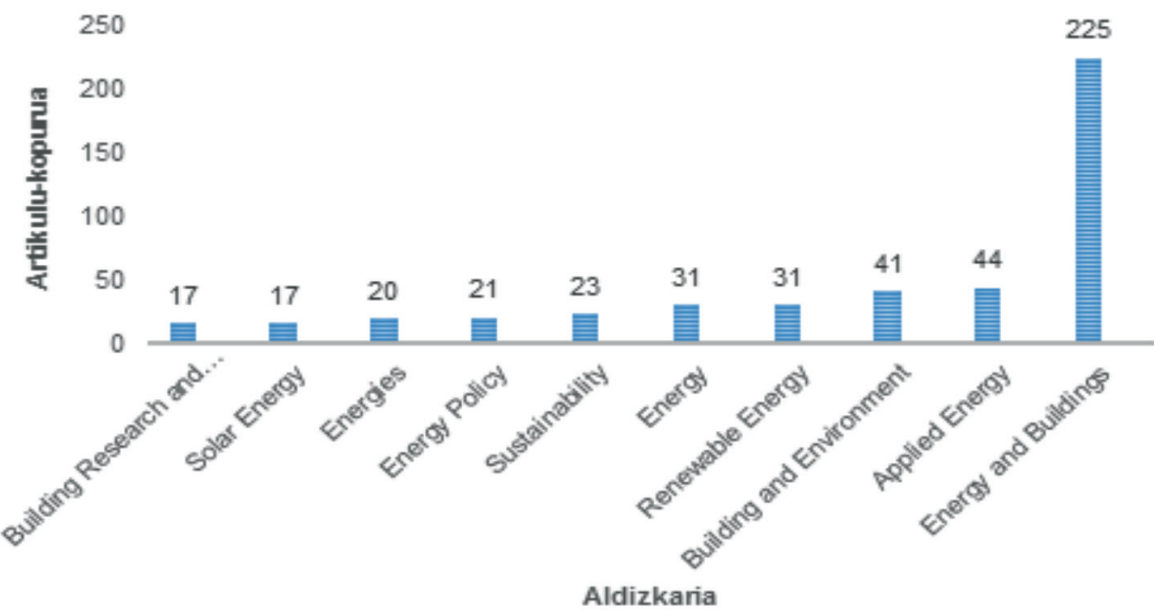

5. irudia. WoSen artikulu gehien publikatutako 10 aldizkariak.

Zientzia ikerketaren profila burutzeko, gehien aipatzen diren artikuluak identifikatu dira (ikusi 2.taula). 


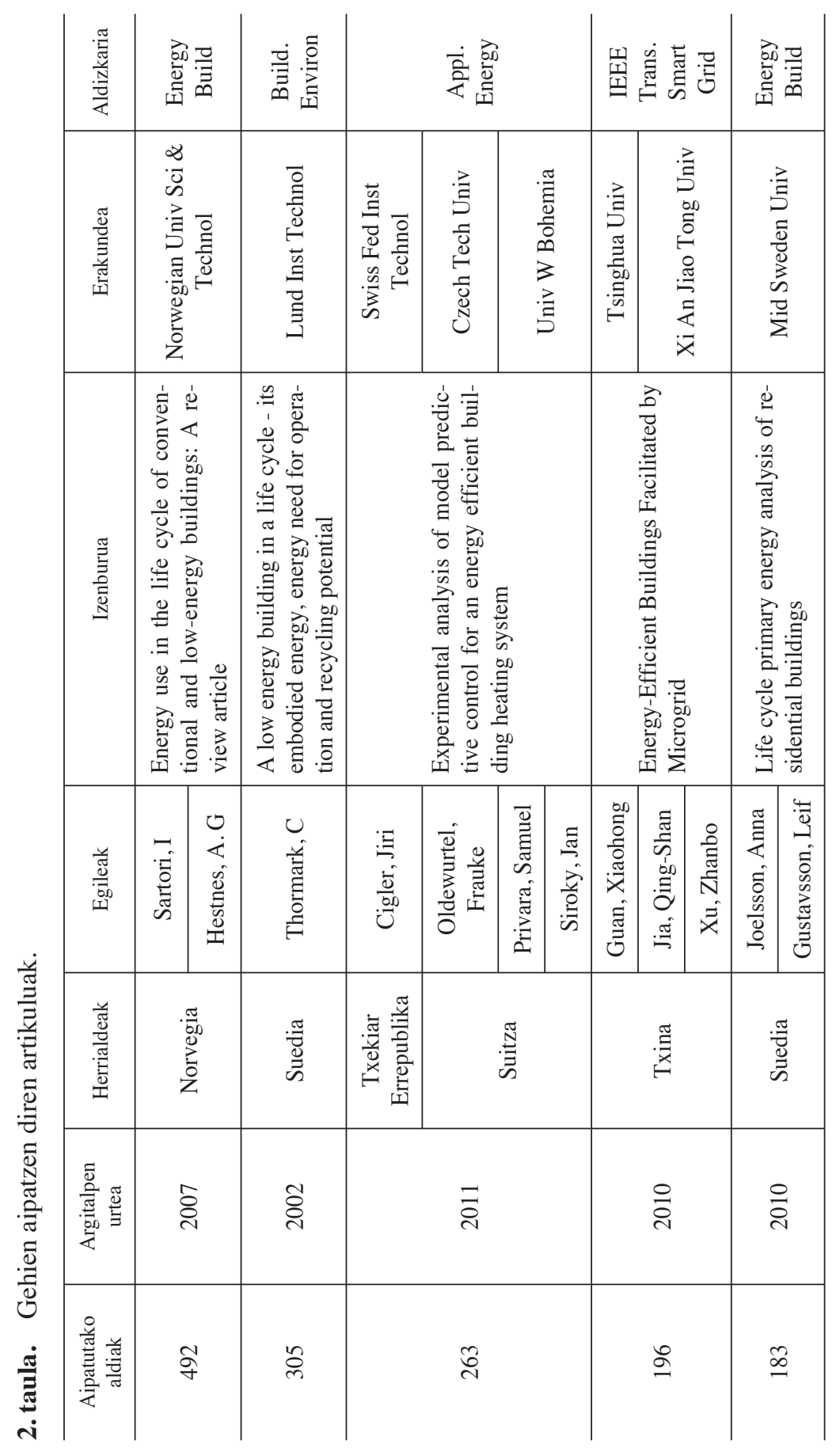


Izaskun Alvarez, Enara Zarrabeitia Bilbao, Itziar Martinez de Alegria Mancisidor, Jasone Aranburu

Artikulu horiek ahalbidetzen dute aztertzen ari den jakintza-arloaren ezagutza iturri garrantzitsuenen identifikazioa. Energy and Building aldizkaria argitalpen gehien dituen aldizkaria izateaz gain, gehien aipatzen den artikuluaren argitalpen-aldizkaria da ere. Horrekin batera, gehien aipatzen diren artikuluen jatorria nagusiki unibertsitateak dira, eta Europako herrialdeetan daukate abiaburua.

\subsection{Bistaratze-sareak}

Aurreko ataletan lortutako emaitzen osagarri bezala, gako-hitzen taldekatzea egin da, zientzia-mailan garatzen ari diren kontsumo baxuko eraikinen ezagutza alorrak identifikatzeko asmoz. Gako-hitzek bat-etortze altua partekatzen dutenean, terminoen klusterizazioa suertatzen da, eta kluster bakoitzak ia zero energia kontsumitzen duten eraikinekin erlazionaturik dagoen kontzeptu berezi bat adieraziko du.

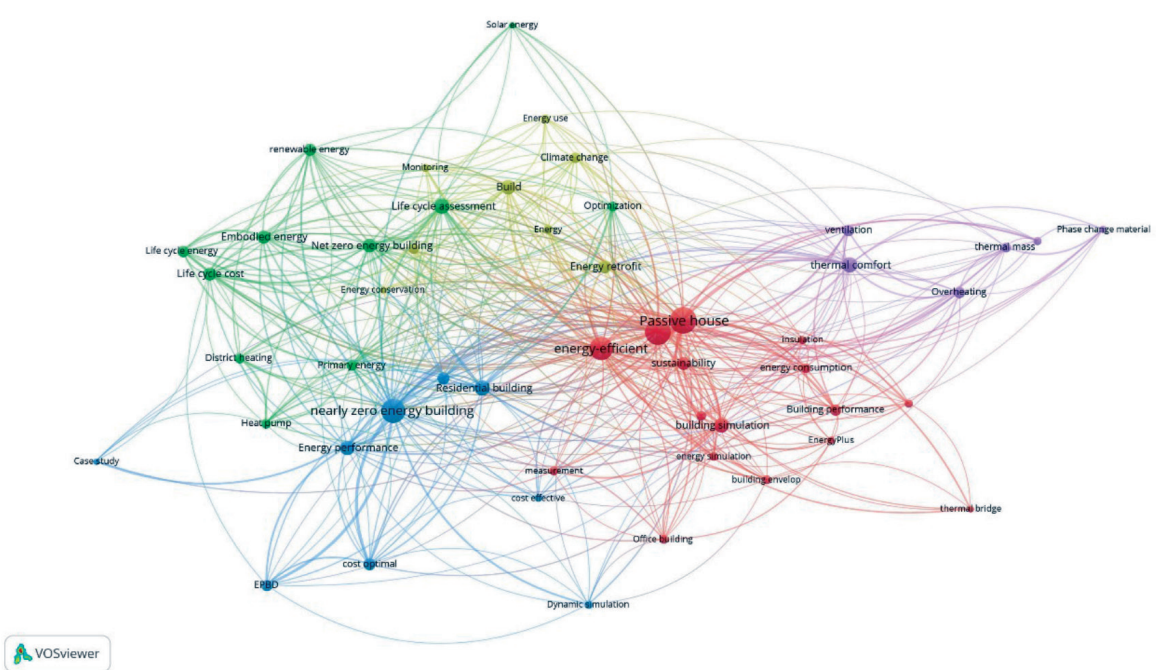

6. irudia. Argitalpenen hitz-gakoen bat-etortze bistaratze-mapa.

6. irudiak erakusten du gehien aipatu diren WoSen argitalpenen gako-hitzen bat-etortze sarea; VOSviewer tresna erabili da sarea sortzeko. Kontzeptu-mapak erakusten du gako-hitz garrantzitsuenak direla «nearly zero energy building», «passive house», «low energy building», «net zero energy building», «life cycle assessment», «energy performance», «energy-efficient», «residential building», «thermal comfort» eta «energy retrofit», zeinak kontsumo-baxuko eraikinen ezagutza zientifikoaren ikerketa-gai nagusiak islatzen baitituzte. Klusterizazio teknikak 5 talde hauek 
definitu ditu: Passivhaus estandarra eta kontsumo baxuko eraikinak, net Zero Energy Building etxebizitzak eta kostua, bizitza-zikloa eta berokuntza-energia, konfort termikoa, eta energia eta klima-aldaketa.

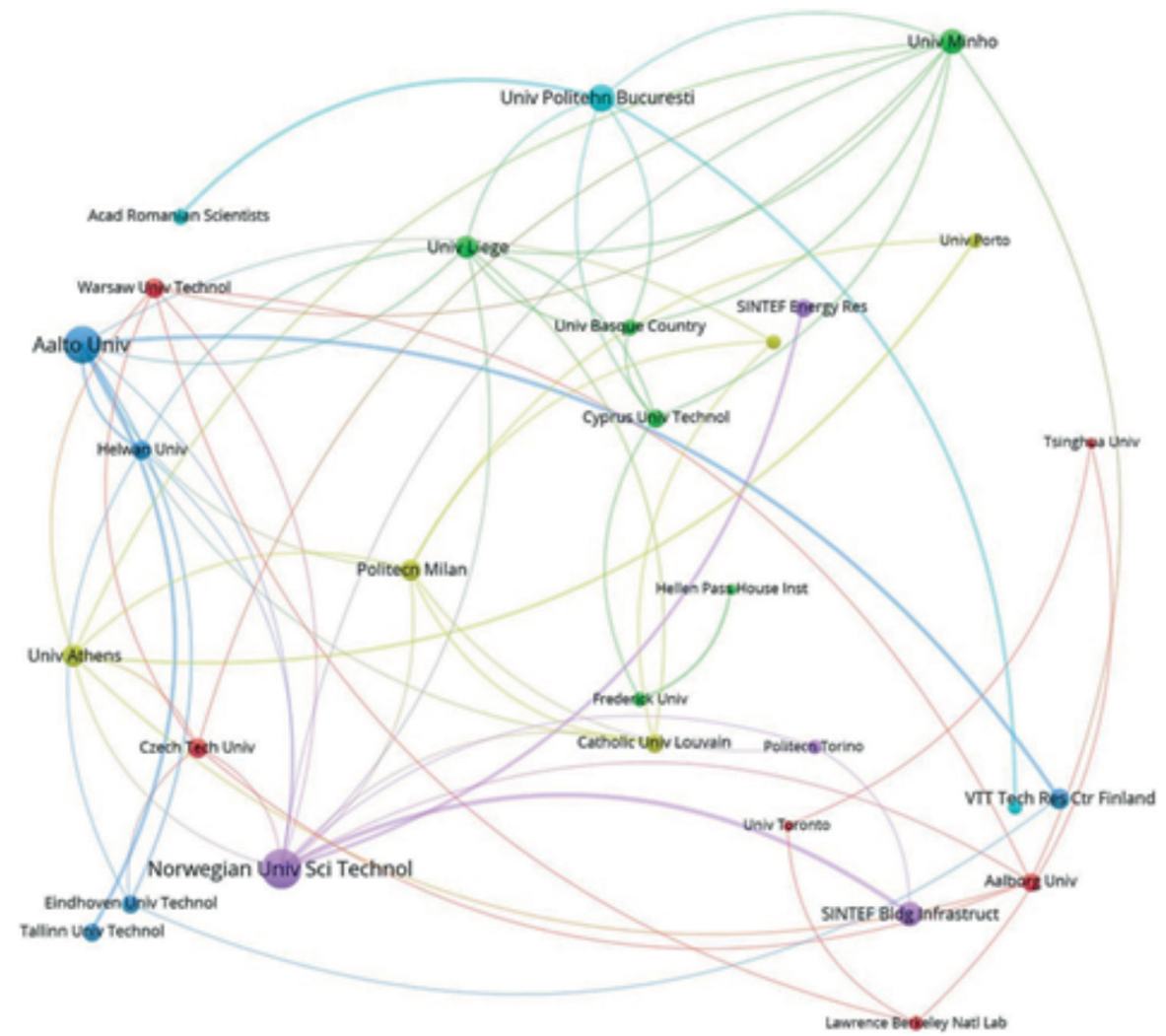

7. irudia. Erakundeen ko-gertaeren eta erlazioen bistaratze-mapa.

Zientzia-transferentziari dagokionez, erakundeen arteko erlazioak aztertu dira ezagutzaren elkarlana erakusteko. Horretarako, ikerketa erakundeen bat-etortzeaz baliatu gara, eta taldekatze bakoitzak erakundeen erlazioen sendotasuna adierazten du. Horrela izanda, taldekatzeak edo klusterizazioak «Norwegian University», «Aalto University», «Politehnica University of Bucarest», «SINTEF building in frastructure», «Minho University» definitzen ditu erlazio-lotura sendoenekin (ikusi 7. irudia). Aipatzekoa da batera azaltze honetan daukan sendotasun-erlazioak Euskal Herriko Unibertsitatea 22. lekuan kokatzen duela. 
Izaskun Alvarez, Enara Zarrabeitia Bilbao, Itziar Martinez de Alegria Mancisidor, Jasone Aranburu

\section{ONDORIOAK}

Emaitza orokorrek azaltzen dute, zientzia ikuspegiaren aldetik, ia zero energia kontsumitzen duten etxebizitzak zientzia ekoizpenean azkar eskuratzen dagoela aditasuna, eta honek eragina dauka I+Gn. Azken bost urteetan, ia zero energia kontsumitzen duten eraikinen inguruko artikulu zientifikoen \% 67,31 argitaratu da. Argitalpen horiei dagokienez, argitaratzen emankorrenak diren herrialdeak ez daude geografikoki kontzentratuta, eta Italia da argitalpen zifra handiena duen herrialdea (\% 11). Bigarren, Erresuma Batua da, eta nahikoa hurbiletik jarraitzen diote Suediak eta AEBk. Hala ere, WoS-en gehien argitaratu duten herrialdeen artean, denak europarrak dira, AEB eta Txina izan ezik. Gainera, artikulu gehien dituzten erakundeei dagokienez gailentzen diren erakundeen jatorria nahikoa sakabanatuta dago, eta ez datoz bat gehien argitaratzen duten herrialdeekin; Norvegian (Norwegia University), Finlandian (Aalto University) eta Danimarkan (Denmark Tech. University) finkatuta daude. Gai horretan emankorrena den aldizkaria Energy and Buildings izenekoa da, zeinak artikulu zientifikoen \% 27,33 argitaratzen baititu. Gehien aipatzen den artikulua ere aldizkari horretan argitaratu da. Ezagutzera emate handiena garatzen duten herrialde gehienak europarrak dira, eta nagusiki unibertsitate erakundeak.

Aipagarria da Europako zientzialariek eman dioten bultzada ia zero energia kontsumitzen duten eraikinen ikerketa arloari. Azken urteetan efizientzia energetikoa erronka garrantzitsua bihurtu da, eta horrek eragina izan du zientziaren munduan ezagutza berriak landuz etxebizitzen kontsumo energetikoaren eremuan, besteak beste honako ezagutza-arlo hauetan: isolamendua eta efizientzia; etxebizitzen kostua, energia berriztagarria eta bizi-zikloaren azterketa, eta konfort-termikoa.

\section{ESKER ONAK}

TFM research group taldeari.

\section{BIBLIOGRAFIA}

[1] RICCIU, R., BESAlDUCH, L. A., GALATIOTO, A., CIULlA, G. 2018. «Thermal characterization of insulating materials». Renewable and Sustainable Energy Reviews ,82, 1765-1773.

[2] DODOO, A., GUSTAVSSON, L., SATHRE, R. 2011. «Building energy-efficiency standards in a life cycle primary energy perspective». Energy and Buildings, 43, 1589-1597. 
[3] BRAMBILlA, A., SALVALAI, G., IMPERADORI, M., SESANA, M. M. 2018. «Nearly zero energy building renovation: From energy efficiency to environmental efficiency, a pilot case study». Energy and Buildings, 166, 271-283.

[4] COMMISSION, E.Buildings I Energy, https://ec.europa.eu/energy/en/topics/ energy-efficiency/buildings/ (last time accessed: February 13, 2019).

[5] EUROPEAN COMMISSION, EU Energy Poverty Observatory I EU Energy Poverty Observatory, https://www.energypoverty.eu/ (last time accessed: March 4, 2019).

[6] TOPRISKA, E., KOLOKOTRONI, M., MELANDRI, D., MCGUINESS, S., CECLAN, A., CHRISTOFORIDIS, G., FAZIO, V., HADJIPANAYI, M., HENDRICK, P., KACARSKA, M., PEÑALVO LÓPEZ, E., PETERSEN, K., STEINBRECHER, J. 2018. «The Social, Educational, and Market Scenario for nZEB in Europe». Buildings, 8, 51.

[7] WELLS, L., RISMANCHI, B., AYE, L. 2018. «A review of Net Zero Energy Buildings with reflections on the Australian context». Energy and Buildings, 158, 616-628.

[8] CLARIVATE ANALYTICS, Web of Science Core Collection - Clarivate, https://clarivate.com/products/web-of-science/web-science-form/web-science-core-collection/ (last time accessed: March 6, 2019).

[9] GARECHANA, G., RIO-BELVER, R., CILLERUELO, E., LARRUSCAIN SARASOLA, J. 2015. «Clusterization and mapping of waste recycling science. Evolution of research from 2002 to 2012». Journal of the Association for Information Science and Technology ,66, 1431-1446.

[10] ECK, N. J. VAN, WALTMAN, L., VAN ECK, N. J., WALTMAN, L., ECK, N. J. VAN, WALTMAN, L. 2011. «Text mining and visualization using VOSviewer». ISSI Newsletter, DOI: 10.1371/journal.pone.0054847.

[11] WALTMAN, L., VAN ECK, N. J., NOYONS, E. C. M. 2010. «A unified approach to mapping and clustering of bibliometric networks». Journal of Informetrics, 4, 629-635. 